\title{
Permodelan Tsunami dan Implikasinya Terhadap Mitigasi Bencana di Kota Palu
}

\author{
Rahmat Aris Pratomo1, Iwan Rudiarto²
}

Diterima : 1 April 2013

Disetujui : 30 April 2013

\begin{abstract}
The City of Palu, Central Sulawesi is one of the regions in Indonesia which are vulnerable to tsunami and require a preventive action plan and mitigation to reduce potential risks. This study analyzed tsunami inundation zones and their implications regarding disaster mitigation in the city. This study employed quantitative approach using Geographical Information System (GIS) to map tsunami disaster prone areas. Cost Distance was used to model tsunami disaster; spatial analyst and network analyst were used to analyze the level of danger, vulnerability, and risk of tsunami, and also the establishment of evacuation routes. Analysis indicated the followings: (1) The City of Palu has large potential for tsunami inundation, (2) tsunami danger area comprises 9,63\% of total city area, (3) tsunami vulnerable area 9,83\% of total city area, (4) tsunami risk area 3,83\% of total city area, and (5) there are 50 shelters acting as evacuation points and 108 evacuation routes in around the city. The built up area around the coast of Palu Bay area was identified as having high risk of tsunami disaster. Evacuation routes are scattered in the built up areas with the number of routes corresponding to population density.
\end{abstract}

Key words: tsunami modeling, risk, shelter, evacuation routes, Palu City

\begin{abstract}
ABSTRAK
Kota Palu Sulawesi Tengah adalah salah satu wilayah di Indonesia yang rentan terhadap bencana tsunami dan perlu memiliki suatu rencana tindakan preventif dan mitigasi untuk mengurangi potensi resiko. Studi ini menganalisa zona genangan tsunami dan implikasinya terkait kegiatan mitigasi bencana di Kota Palu. Studi ini menggunakan pendekatan kuantitatif menggunakan Sistem Informasi Geografis (SIG) untuk memetakan wilayah yang rawan bencana tsunami. Studi ini menggunakan cost distance untuk memodelkan bencana tsunami, serta menggunakan spatial analyst dan network analyst untuk menganalisa tingkat bahaya, kerentanan, dan resiko bencana tsunami, serta penentuan rute evakuasi. Analisis mengindikasikan berikut ini: (1) Kota Palu memiliki potensi yang besar terhadap rendaman tsunami, (2) kawasan bahaya tsunami mencakup 9,63\% dari total luas kota, (3) kawasan rentan tsunami 9,83\% total luas kota, (4) kawasan resiko tsunami 3,83\% total luas kota, dan (5) terdapat 50 shelter sebagai lokasi evakuasi dan 108 rute evakuasi di seluruh kota. Kawasan terbangun di wilayah pesisir Teluk Palu teridentifikasi memiliki tingkat resiko bencana tsunami yang tinggi. Jalur evakuasi yang ada tersebar melalui kawasan terbangun dengan jumlah rute yang berbanding lurus dengan kepadatan penduduk
\end{abstract}

Kata kunci: permodelan tsunami, resiko, shelter, rute evakuasi, Kota Palu

\footnotetext{
${ }^{1}$ Mahasiswa Magister Pembangunan Wilayah dan Kota, Universitas Diponegoro

${ }^{2}$ Dosen Jurusan Perencanaan Wilayah dan Kota, Undip, Semarang, Jawa Tengah

Kontak Penulis: aris.gis@gmail.com
} 


\section{PENDAHULUAN}

Indonesia menduduki peringkat kedua sebagai negara yang paling sering dilanda tsunami dengan 71 kejadian atau hampir 9\% dari jumlah tsunami di dunia. Penyebab kenapa Indonesia menduduki peringkat kedua tersebut karena letak geografis Indonesia yang berada pada pertemuan tiga lempeng utama pembentuk kerak bumi, yaitu Lempeng Eurasia yang bergerak ke arah tenggara dan Lempeng Indo-Australia yang bergerak memanjang di Samudera Hindia dari arah utara (Aceh) hingga sekitar Laut Timor di timur dan Lempeng Pasifik yang bergerak di sekitar Samudera Pasifik hingga utara Papua.

Berdasarkan pengalaman historis, kejadian tsunami sangat membahayakan bagi komunitas masyarakat di wilayah pesisir pantai, meskipun daerah tersebut jauh dari kawasan yang rawan gempa bumi (tektonik maupun vulkanik) bawah laut. Dampak yang dapat ditimbulkan akibat bencana tsunami sangatlah besar, yaitu dapat berupa kematian, kehilangan harta benda, kehancuran sarana dan prasarana khususnya di daerah pesisir pantai, menimbulkan gangguan ekonomi dan bisnis, bahkan dapat mengganggu keadaan psikologis (traumatic) masyarakat.

Negara-negara atau kota yang rentan terhadap bencana tsunami sudah selayaknya memiliki suatu tindakan preverentif dan mitigasi untuk menghadapi serangan tsunami baik itu pra maupun pasca agar mengurangi resiko yang ditimbulkan bencana tsunami, sesuai dengan Undang-undang No. 24 Tahun 2007 tentang Penanggulangan Bencana. Tindakan yang dapat dilakukan antara lain dengan pembuatan dokumen mitigasi bencana, pembangunan lokasi evakuasi yang dapat digunakan baik yang bersifat alamiah berupa bukit, maupun buatan berupa bangunan khusus untuk penampungan masyarakat saat terjadi bencana. Selain itu, pembuatan rambu evakuasi dan rute evakuasi serta penyuluhan kepada masyarakat agar masyarakat menjadi terlatih dan tidak panik saat bencana tsunami benar-benar terjadi.

Salah satu dari sekian banyak wilayah di bagian timur Indonesia yang menyimpan potensi tsunami yang cukup besar adalah Kota Palu dan sekitarnya. Tercatat telah terjadi tiga kali kejadian di sekitar Teluk Palu, yaitu pada tahun 1927, 1968 dan 1996, sementara sekitar Kota Palu (Sulawesi Tengah) terdapat 6 kejadian. Wilayah Kota Palu dan sekitarnya terdapat beberapa potongan sesar yang sangat berpotensi membangkitkan gempa bumi yang cukup kuat. Sesar tersebut adalah Sesar Palu-Koro yang memanjang dari Palu ke arah Selatan dan Tenggara melalui Sulawesi Selatan bagian Utara menuju ke selatan Bone sampai di Laut Banda.

Khusus kejadian-kejadian tsunami di Kota Palu dan sekitarnya, belum ada suatu kajian model bahaya bencana tsunami berupa jangkauan rendaman tsunami yang merupakan hal penting dalam kegiatan mitigasi. Karena sebelum melakukan kegiatan mitigasi, diperlukan suatu pendekatan ilmiah terhadap potensi bahaya tsunami yang dapat terjadi di sekitar Kota Palu. Untuk itu, dibutuhkan suatu kajian berupa permodelan tsunami dan implikasinya terhadap mitigasi bencana di Kota Palu yang diharapkan dapat menjadi masukan dalam kegiatan mitigasi bencana di Kota Palu.

Tujuan utama penelitian ini adalah untuk mengetahui zona genangan tsunami dan implikasinya terhadap kegiatan mitigasi bencana di Kota Palu dengan beberapa sasaran yaitu membuat permodelan zona genangan tsunami yang ada di sekitar Kota Palu dengan skenario variasi ketinggian run-up pada garis pantai, mengetahui daerah resiko bencana tsunami di Kota Palu, menemukan lokasi evakuasi apabila terjadi bencana tsunami di Kota Palu, serta menentukan rute evakuasi tsunami di Kota Palu. 


\section{METODE PENELITIAN}

Penelitian ini menggunakan pendekatan kuantitatif dengan metode analisis yang digunakan meliputi metode analisis deskriptif dan analisis evaluatif. Pada permodelan tsunami, digunakan pendekatan model penggenangan/ inundasi dengan bantuan spatial analyst tools yang ada pada software SIG. Parameter yang digunakan adalah tinggi gelombang tsunami pada garis pantai, kelerengan wilayah, dan koefisien kekasaran permukaan (surface roughness coefficient). Persamaan yang digunakan dalam permodelan genangan tsunami dalam penelitian ini dapat dilihat pada persamaan berikut: (Berryman, 2006 dalam Putra, 2008)

$$
H_{\text {loss }}=\left(\frac{16.7 \cdot n^{2}}{H_{0}^{1 / 3}}\right)+0.5 \times \sin S
$$

Keterangan:

Hloss = Kehilangan ketinggian tsunami per $1 \mathrm{~m}$ jarak genangan/inundasi

$\mathrm{n} \quad=$ Koefisien kekasaran permukaan

Ho = Ketinggian gelombang tsunami di garis pantai

$\mathrm{S}=$ Besarnya lereng permukaan

Bentuk mitigasi bencana tsunami yang dibahas dalam penelitian ini adalah tindakan non fisik berupa pengkajian bencana, meliputi analisa kawasan bahaya tsunami, kawasan rentan tsunami, kawasan resiko bencana tsunami, dan penentuan lokasi evakuasi berdasarkan ketentuan building code serta penentuan rute evakuasi. Teknik analisis yang digunakan untuk kajian mitigasi tersebut adalah teknik overlay dengan bantuan tools spatial analyst dan network analyst.

\section{SEJARAH TSUNAMI DAN KARAKTERISTIK WILAYAH KOTA PALU}

\section{Sejarah Gempa Bumi danTsunami di Kota Palu}

Daerah Palu merupakan salah satu kawasan seismik aktif di Indonesia karena dilalui segmentasi sesar yang sangat berpotensi membangkitkan gempa bumi kuat, yaitu Sesar Palu-Koro yang memanjang dari Palu ke arah Selatan dan Tenggara. Ditinjau dari kedalaman gempa buminya, aktivitas gempa bumi di zona ini tampak didominasi oleh gempa bumi kedalaman dangkal antara o hingga 60 kilometer. Dengan demikian, aktivitas tersebut beresiko untuk menimbulkan tsunami.

Kerawaan gempa bumi dan tsunami di Kota Palu dan sekitarnya ini terbukti dengan beberapa catatan sejarah gempa bumi dan tsunami yang berlangsung sejak tahun 1927, seperti gempa bumi dan tsunami Palu 1927, gempa bumi dan tsunami Tambu 1968, dan gempa bumi dan tsunami Toli-Toli dan Palu 1996 (Daryono, 2011). Berikut merupakan lokasi episentrum kejadian gempa bumi yang membangkitkan tsunami yang menyerang Kota Palu.

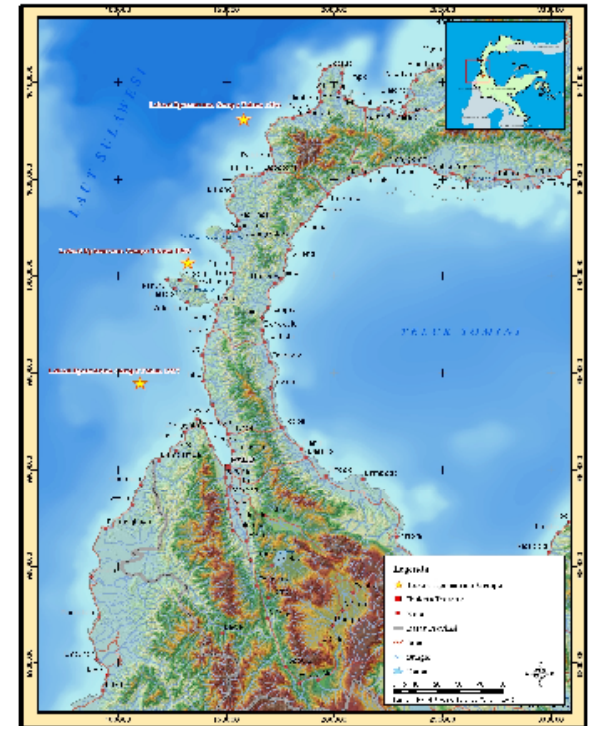

Sumber: Hasil Analisis Penyusun, 2013

GAMBAR 1

PETA LOKASI GEMPA PEMBANGKIT TSUNAMI DI KOTA PALU 


\section{Batas Administrasi dan Letak Geografis Kota Palu}

Kota Palu secara geografis berada di tengah wilayah Kabupaten Donggala. Tepatnya sepanjang bibir pantai Teluk Palu atau memanjang dari timur ke barat, terletak di sebelah utara garis katulistiwa pada koordinat $0,35^{\circ}-1,20^{\circ}$ Lintang Utara dan $120^{\circ}-122,09^{\circ}$ Bujur Timur. Luas wilayah Kota Palu adalah $369,46 \mathrm{~km}^{2}$ atau 36.946 ha dan terdiri atas 8 Kecamatan. Lebih jelas mengenai batas administrasi dan letak geografis Kota Palu, dapat dilihat pada Gambar 2.

\section{Penggunaan Lahan Kota Palu}

Penjelasan mengenai jenis dan luasan penggunaan lahan Kota Palu dapat dilihat pada Tabel 1.

TABEL 1

\section{LUAS PENGGUNAAN LAHAN KOTA PALU TAHUN 2012}

\begin{tabular}{lll}
\hline $\begin{array}{l}\text { Jenis } \\
\text { Penggunaan Lahan }\end{array}$ & $\begin{array}{l}\text { Luas Wilayah } \\
\left(\mathrm{Km}^{2}\right)\end{array}$ & Luas Wilayah (\%) \\
\hline Hutan & 186,315 & 50,43 \\
\hline Semak Belukar & 69,327 & 18,76 \\
\hline Kebun & 39,439 & 10,76 \\
\hline Ladang & 5,215 & 1,41 \\
\hline Lahan Kosong & 11,962 & 3,24 \\
\hline Permukiman & 35,401 & 9,58 \\
\hline Rumput & 0,221 & 0,06 \\
\hline Sawah & 12,215 & 3,31 \\
\hline Jalan & 4,025 & 1,09 \\
\hline Tambak & 0,257 & 0,07 \\
\hline Sungai & 5,083 & 1,38 \\
\hline TOTAL & $\mathbf{3 6 9 . 4 6}$ & $\mathbf{1 0 0 , 0 0}$ \\
\hline
\end{tabular}

Sumber: RTRW Kota Palu Tahun 2006-2025 dan Data Spasial Kota Palu Tahun 2012


Sumber: Hasil Analisis Penyusun, 2013

GAMBAR 2

WILAYAH ADMINISTRASI KOTA PALU (A) DAN 


\section{LOKASI GEMPA PEMBANGKIT TSUNAMI DI KOTA PALU (B)}

\section{ANALISIS}

\section{Permodelan zona genangan tsunami di sekitar Kota Palu}

Permodelan zona genangan tsunami dilakukan dengan menggunakan lima skenario ketinggian run-up pada garis pantai, yakni 1m, 2m, 5m, 10m, dan 15m. Dari permodelan tersebut ditunjukkan bahwa pada skenario ketinggian run-up 1 meter, rendaman tsunami menggenangi wilayah Kota Palu seluas 328,2 Ha dimana mayoritas wilayah yang tergenang masih berupa lahan kosong dan sedikit permukiman. Genangan terluas terdapat di Kecamatan Palu Utara dengan luas 112,06 ha atau 34,14\% dari total luas wilayah yang tergenang tsunami dengan ketinggian 1 meter. Wilayah genangan terkecil berada di Kecamatan Palu Timur, yang hanya seluas 14,60 ha atau $4,45 \%$ dari total luas wilayah genangan tsunami 1 meter.

Pada permodelan tsunami dengan ketinggian run-up 2 meter ini, genangan tsunami menjalar hingga tambak-tambak penduduk. Total luas wilayah yang tergenang dalam skenario ini adalah 706,25 Ha atau meningkat 53,52 \% dari luasan genangan tsunami pada skenario run-up 1 meter. Kecamatan dengan wilayah genangan terbesar adalah Kecamatan Palu Utara seluas 202,5 ha atau 30,09\%. Sedangkan wilayah genangan terkecil adalah Kecamatan Palu Timur dengan luasan 33,85 ha dengan persentase $4,79 \%$.

Pada permodelan tsunami dengan ketinggian run-up 5 meter, genangan tsunami semakin menjalar ke wilayah daratan. Berdasarkan hasil permodelan diperoleh hasil bahwa genangan tsunami dengan ketinggian 5 meter telah memasuki wilayah permukiman penduduk ke arah pusat Kota Palu. Wilayah dengan luas genangan terkecil adalah Kecamatan Palu Timur dengan luas 117,29 $\mathrm{Ha}$, sedangkan wilayah dengan genangan terluas adalah Kecamatan Palu Utara dengan luas $428,47 \mathrm{Ha}$ (28,12\% dari total luas wilayah genangan pada ketinggian run-up 5 meter).

Pada ketinggian 10 meter, genangan tsunami telah menjalar hingga Sungai Palu, wilayah permukiman di sekitar sungai, sebagian permukiman dan lahan kosong di sepanjang pantai bagian barat sisi timur, dan permukiman-permukiman lain yang mengarah ke arah pusat kota. Luas genangan pun semakin besar, yaitu 2380, $59 \mathrm{Ha}$, dimana luas genangan terbesar berada di Kecamatan Palu Utara (619,39 Ha). Bahkan, Kecamatan Palu Selatan dan Kecamatan Tatanga yang sebelumnya tidak tergenang tsunami, diprediksikan turut tergenang seluas 0,10 Ha dan 7,92 Ha jika terjadi tsunami dengan ketinggian 10 meter.

Permodelan tsunami dengan ketinggian run-up 15 meter tergolong tingkat bahaya sangat tinggi. Hasil permodelan pada ketinggian 15 meter menunjukkan bahwa genangan tsunami semakin meluas dan menjalar ke arah pusat Kota Palu. Luasan genangan tsunami mencapai $3458,56 \mathrm{Ha}$ atau meluas 31,16\% dari luasan genangan tsunami pada ketinggian 10 meter. Luas genangan terbesar berada di Kecamatan Palu Utara dan luas genangan terkecil berada di Kecamatan Palu Selatan dengan luas masing-masing 842,84 Ha dan 34,94 Ha. Permodelan tsunami dengan ketinggian run-up 15 meter dapat dilihat pada Gambar 3A.

\section{Zona Bahaya Tsunami}

Secara umum, luas bahaya tsunami Kota Palu adalah 3558,56 ha atau \pm 9,63\% dari luas wilayah Kota Palu (luas Kota Palu adalah 36.946 ha). Seluruh wilayah kecamatan yang ada di Kota Palu memiliki potensi terkena bahaya tsunami, baik mulai tingkat bahaya rendah hingga tingkat 
bahaya sangat tinggi, kecuali Kecamatan Palu Selatan dan Kecamatan Tatanga yang tidak memiliki bahaya tsunami yang sangat tinggi.

Kecamatan yang mempunyai luas bahaya tsunami terbesar adalah Kecamatan Palu Utara, yaitu 842,84 Ha. Luas Kecamatan Palu Utara adalah 3171 Ha sehingga luas kecamatan yang diprediksikan tergenang adalah $26,58 \%$ dari luas wilayah total. Kecamatan dengan luas bahaya tsunami terkecil adalah Kecamatan Palu Selatan. Zona bahaya tsunami dapat dilihat pada Gambar 3B.
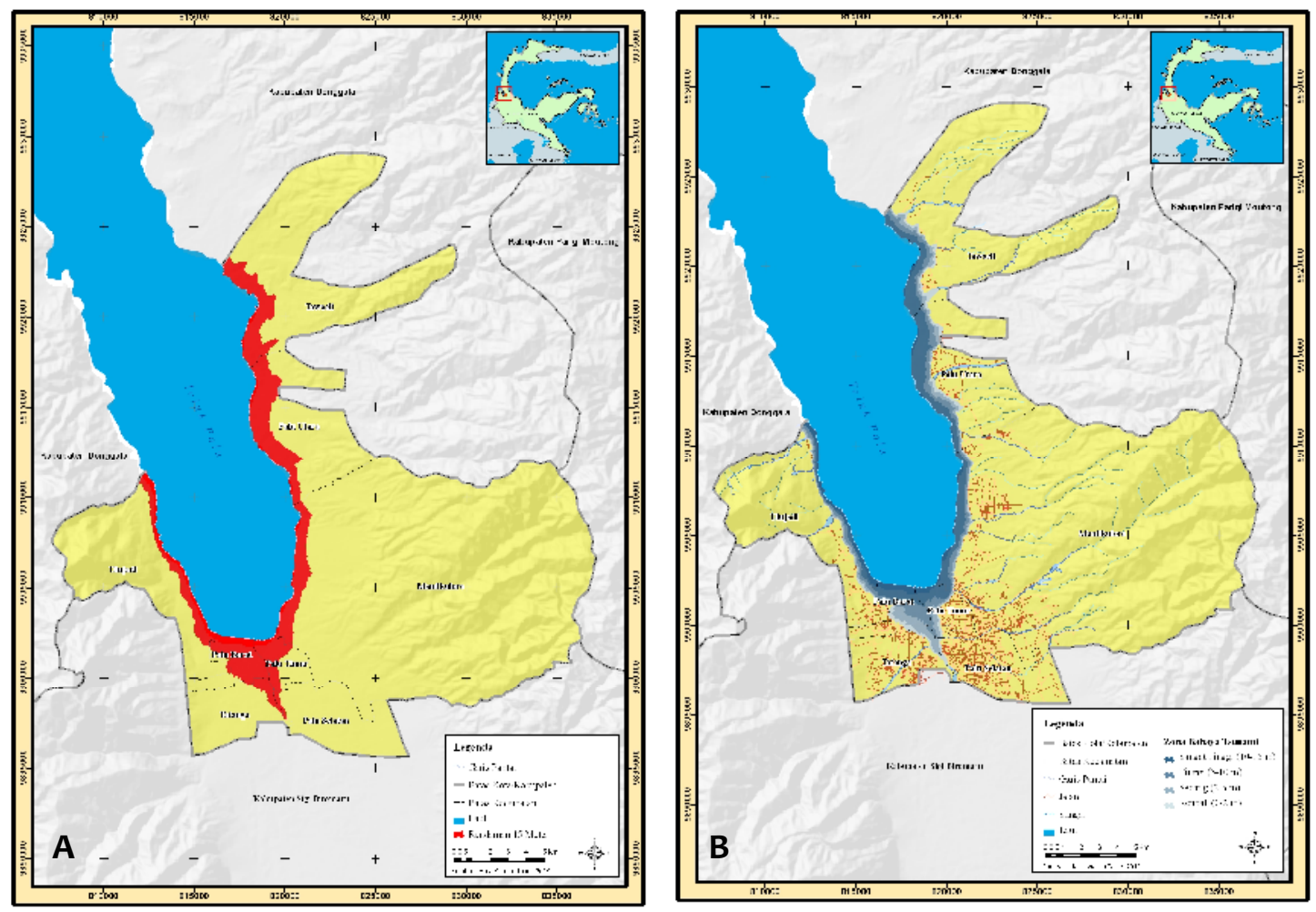

Sumber: Hasil Analisis Penyusun, 2013

\section{GAMBAR 3 \\ PERMODELAN TSUNAMI DENGAN KETINGGIAN RUN-UP 15 MTER (A) DAN ZONA BAHAYA TSUNAMI KOTA PALU (B)}

\section{Zona Kerentanan Tsunami}

Parameter yang digunakan dalam penentuan tingkat kerentanan Kota Palu terhadap tsunami adalah kepadatan bangunan, jumlah penduduk wanita, balita, dan manula, serta kepadatan penduduk. Dari parameter tersebut, diperoleh 4 klasifikasi tingkat kerentanan tsunami di Kota Palu, yaitu kerentanan rendah, sedang, tinggi, dan sangat tinggi.

Secara umum wilayah Kota Palu termasuk dalam klafisikasi kerentanan tinggi terhadap tsunami. Wilayah yang mempunyai kerentanan tinggi di Kota Palu adalah seluas 1190,91 Ha atau $\pm 32,78 \%$ dari total wilayah rentan di Kota Palu. Wilayah dengan kerentanan rendah seluas $1103,20 \mathrm{Ha}$, wilayah kerentanan sedang seluas 1076,50 Ha, serta wilayah kerentanan sangat tinggi seluas 262,61 Ha. Jika dirinci per kategori kecamatan, kecamatan dengan luas kerentanan rendah terbesar adalah Kecamatan Kecamatan Palu Utara $(288,57 \mathrm{Ha})$, kecamatan dengan luas kerentanan sedang terbesar adalah Kecamatan Mantikulore $(304,61 \mathrm{Ha})$, kecamatan dengan luas kerentanan tinggi terbesar adalah Kecamatan Mantikulore (359,87 Ha), dan kecamatan dengan luas kerentanan sangat tinggi terbesar adalah Kecamatan Palu Selatan (179,54 Ha). 


\section{Zona Resiko Bencana Tsunami}

Resiko bencana tsunami merupakan hasil interaksi antara potensi bahaya (hazard) dengan tingkat kerentanan daerah (vulnerability). Luas wilayah beresiko tsunami di Kota Palu yang adalah 1416l,02 Ha. Dari luas wilayah tersebut, mayoritas merupakan wilayah beresiko tinggi, yaitu seluas 710,55 Ha. Jika dirinci per kategori, wilayah beresiko rendah mempunyai luas 90,91 Ha dengan wilayah terluas di Kecamatan Palu Utara $(31,34 \mathrm{Ha})$, wilayah beresiko sedang seluas 402,59 Ha dengan wilayah terluas di Kecamatan Ulujadi (127,15 Ha), serta wilayah beresiko sangat tinggi seluas 211,97 Ha dengan luasan terbesar di Kecamatan Palu Timur (126,46 Ha).


Sumber: Hasil Analisis Penyusun, 2013

\section{ZONA KERENTANAN TSUNAMI KOTA PALU (A) DAN ZONA RESIKO TSUNAMI KOTA PALU (B)}

\section{Lokasi Rawan dan Lokasi Evakuasi}

Lokasi rawan yaitu merupakan lokasi kawasan terbangun yang mengalami penggenangan (termasuk zona resiko) ataupun yang dekat dengan lokasi penggenangan. Berdasarkan kondisi dilapangan, terdapat 108 lokasi rawan yang dijadikan bangkitan dalam penentuan rute evakuasi. Kemudian, berdasarkan kriteria prioritas lokasi evakuasi di atas dan pengamatan di lapangan, diperoleh lokasi evakuasi sebanyak 161 unit, dimana sebagian besar bangunan yang dapat digunakan sebagai shelter berupa bangunan peribadatan dan juga bangunan pemerintahan serta pendidikan.

\section{Rute Evakuasi}

Jaringan yang dipergunakan dalam pembuatan rute evakuasi tsunami yaitu jaringan jalan. Nilai pada tiap segmen jalan adalah waktu tempuh tiap segmen dengan memasukkan nilai waktu rata-rata orang berjalan yaitu sebesar $0,75 \mathrm{~m} /$ detik. Berdasarkan hasil penentuan rute evakuasi, 
diperoleh sebanyak 108 rute evakuasi terpilih dan dari 161 bangunan/shelter yang dapat dijadikan sebagai lokasi evakuasi, terdapat 50 lokasi yang terpilih. Lokasi tersebut terbagi lagi dalam dua kelompok berdasarkan lokasinya yaitu didalam kawasan yang terkena resiko tsunami maupun kawasan yang aman terhadap resiko tsunami.
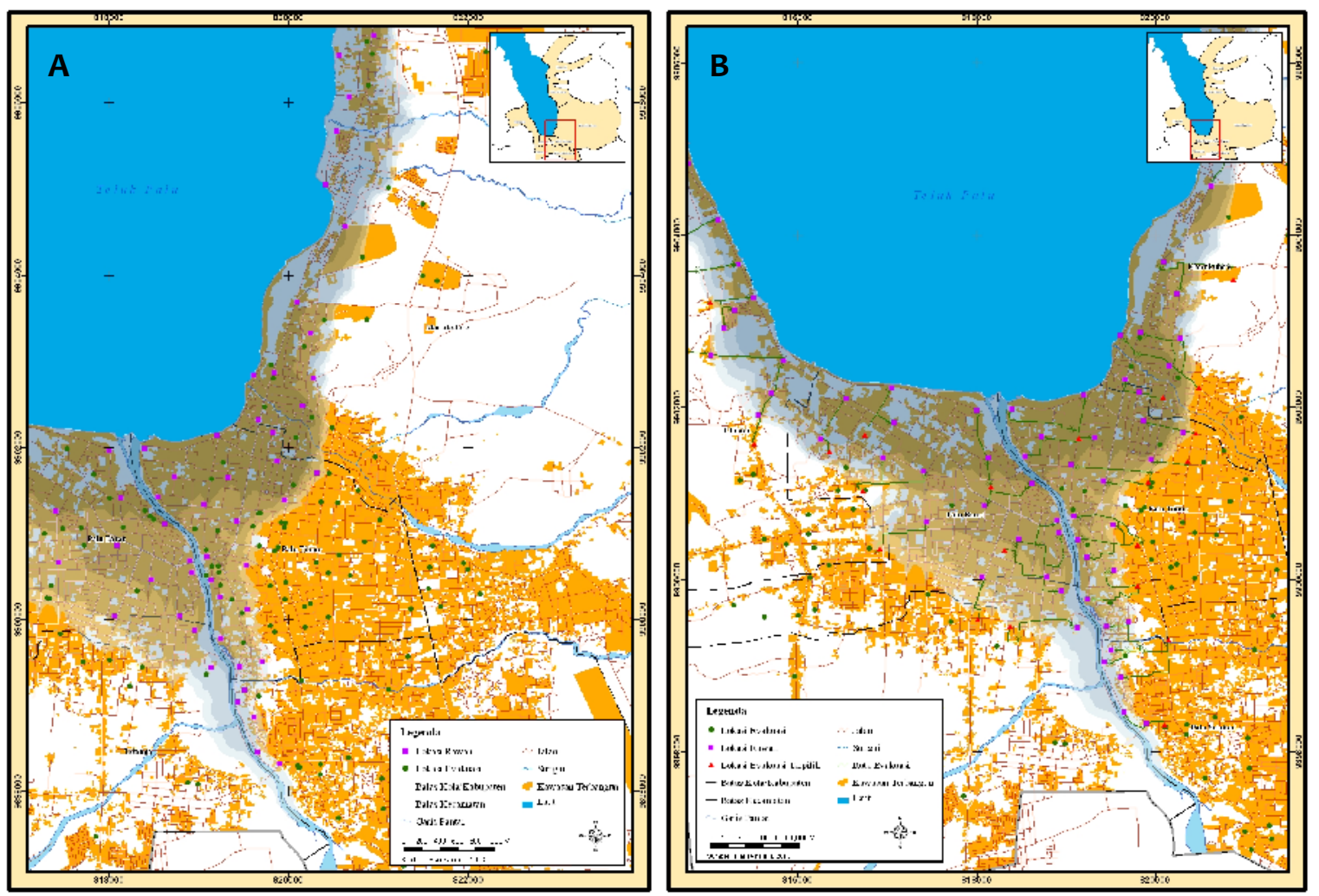

Sumber: Hasil Analisis Penyusun, 2013

\section{GAMBAR 5 \\ LOKASI RAWAN DAN LOKASI EVAKUASI BENCANA TSUNAMI KOTA PALU (A) DAN RUTE EVAKUASI BENCANA TSUNAMI KOTA PALU (B)}

\section{KESIMPULAN}

Permodelan tsunami merupakan suatu langkah awal untuk menilai sejauh mana potensi yang dimiliki oleh Kota Palu terhadap bencana tsunami. Hasil dari permodelan ini dapat dijadikan masukan secara langsung untuk mendeliniasi wilayah yang bahaya terhadap tsunami. Tindakan yang dilakukan sebagai implikasi terhadap bentuk mitigasi bencana tsunami di Kota Palu adalah mitigasi pasif atau non fisik yaitu berupa kajian kebencanaan meliputi analisa kawasan bahaya tsunami, kawasan rentan tsunami, kawasan resiko bencana tsunami, dan penentuan lokasi evakuasi berdasarkan ketentuan building code serta penentuan rute evakuasi. Secara geografis, Kota Palu memiliki potensi yang sangat besar terhadap rendaman dari gelombang tsunami. Kawasan terbangun di Kota Palu terutama yang terletak di wilayah pesisir Teluk Palu yang memiliki tingkat resiko bencana tsunami yang cukup tinggi, sedangkan jalur yang digunakan sebagai rute evakuasi tersebar melalui kawasan terbangun dengan jumlah rute yang berbanding lurus dengan kepadatan penduduk yang ada di kawasan tersebut. Bangunan/shelter yang terpilih sebagai bangunan evakuasi berdasarkan kriteria bangunan evakuasi tersebar mayoritas di wilayah yang tidak beresiko tsunami. Namun, ada beberapa 
lokasi evakuasi yang berada dalam wilayah yang beresiko terkena bencana tsunami. Mengutamakan pengintegrasian tindakan mitigasi bencana tsunami di Kota Palu ke dalam bentuk dokumen tata ruang seperti Dokumen Peraturan Daerah (Perda) RTRW Kota Palu, RDTRK, izin lokasi, dan Izin Mendirikan Bangunan (IMB) sesuai dengan karakteristik potensi bencana tsunami di Kota Palu. Pentingnya penataan ruang yang berbasis mitigasi bencana tsunami ini juga telah didukung dan dilandasi oleh undang-undang seperti UU No. 25 Tahun 2004 tentang Sistem Perencanaan Pembangunan Nasional (SPPN), UU No. 24 Tahun 2007 tentang Penanggulangan Bencana, UU No. 26 Tahun 2007 tentang Penataan Ruang, serta UU No. 27 Tahun 2007 tentang Pengelolaan Pesisir dan Pulau-Pulau Kecil.

\section{DAFTAR PUSTAKA}

ADPC. 2002. Replication of Urban Disaster Mitigation Initiatives. Bandung: ITB.

Aris, Rahmat. 2009. "Arahan Penataan Guna Lahan di Kawasan sekitar Bandar Udara Mutiara Kota Palu”. Skripsi. Fakultas Teknik Universitas Brawijaya, Tidak dipublikasikan.

Awotona, Adenrele. 1997. Reconstruction After Disaster: Issues and Practices. Aldershot: Ashgate.

Bapeda Kota Palu. 2006. Rencana Tata Ruang Wilayah Kota Palu Tahun 2006-2025. Palu: Pemerintah Kota Palu.

Berryman, K. 2006. Review of Tsunami Hazard and Risk in New Zealand. New Zealand: Institute of Geological and Nuclear Science.

Borah, R. (2007). Tsunami Hazard and Damage Assessment. Bangkok: Geoinformatics Center, Asian Institute of Technology (AIT).

Budiarjo, A. 2006. "Evacuation Shelter Building Planning For Tsunami-Prone Area; A Case Study Of Meulaboh City, Indonesia”. Thesis dipublikasikan. Netherlands: International Institute For Geo-Information Science And Earth Observation

Daryono. 2011. Tataan Tektonik dan Sejarah Kegempaan Palu, Sulawesi Tengah. Artikel Kebumian. Badan Meteorologi Klimatologi dan Geofisika.

Davidson, Rachael A. 1997. An UrbanEarthquake Disaster Risk Index. Department of Civil Engineering Stanford University: California.

Diposaptono, S dan Budiman. 2008. Hidup Akrab dengan Gempa dan Tsunami. Bogor: Buku Ilmiah Populer.

Firmansyah. 1998. "Identiflkasi Resiko Bencana Gempabumi dan Implikasinya Terhadap Penataan Ruang Di Kotamadya Daerah Tingkat II Bandung". Tesis Magister Institut Teknologi Bandung, Tidak dipublikasikan.

Illyas, Tommy. 2006. Mitigasi Gempa dan Tsunami di Daerah Perkotaan. Seminar Bidang Kerekayasaan Fakultas Teknik-Universitas Samratulangi.

Kaharuddin, MS. 2011. Perkembangan Tektonik dan Implikasinya terhadap Potensi Gempa dan Tsunami di Kawasan Pulau Sulawesi. Proceedings JCM Makassar.

Putra, Rudiansyah. 2008. "Kajian Risiko Tsunami terhadap Bangunan Gedung Non-hunian dengan Skenario Variasi Ketinggian Run-up pada Garis Pantai (Studi Kasus Kota Banda Aceh, Indonesia)". Tesis. Sekolah Pascasarjana UGM Yogyakarta, Tidak dipublikasikan.

Sea Defence Consultants. 2007. Pedoman perencanaan Pengungsian tsunami (Tsunami Refuge Planning). Aceh: Sea Defence Consultants.

UNESCO-IOC. 2006. Rangkuman Istilah Tsunami. Informasi Dokumen IOC No. 1221. Paris: UNESCO. UNDP. 2003. Tinjauan Umum Manajemen Bencana (Edisi 2). New York: UNDP. 